\title{
FAKTOR-FAKTOR YANG BERHUBUNGAN DENGAN MOTIVASI IBU DALAM MEMBAWA BALITA KE POSYANDU
}

\author{
Rahmaniza \\ STIKes Al-Insyirah Pekanbaru \\ e-mail: rahmaniza91@gmail.com
}

\begin{abstract}
Since posyandu was build the in kelurahan Balai Ahad it is nothing posyandu able to reach up the national target in visiting posyandu. In the posyandu sayang ibu found were only $24 \%$ of children under five years old who come to posyandu meanwhile national target were $80 \%$. The aim of this research was to know about factors that are related with mothers motivation in taking children under five years old to posyandu. The design of research is correlation that used cross sectional. A number of population were 30 people and sample 30 people. The samples this research are all mother who have mother of children under five years and old in Pincuran Tujuh and for taking of data finished by use questionnaires and testing statistic 0,05. The result of this research were $70 \%$ high education and $30 \%$ low education, $60 \%$ good knowledge about posyandu and 40\% bad knowledge, there are 46,67\% positive of posyandu and $53,3 \%$ have negative of posyandu, there are 60\% to get motivation from family and there are $40 \%$ not able to get motivations from family. Respondents who are motivated in taking children under five year old to posyandu were 6 responden (20\%) and 24 respondent (80\%) no not motivated. Based on result of questionnaires are got that 5 respondent $(22,73)$ have high education in taking children under five year old to posyandu, 6 respondent $(33,33 \%)$ have good knowledge, are motivated in taking children under five year old to posyandu, 4 respondents $(22,22 \%)$ have positive thinking, motivated in taking chidren under five year old to posyandu, 5 respondent (22,78\%) get motivation from family and motivated in taking children under five year old to posyandu. Based on the statistical testing of statistic 0,05, got the meaningful relation with mother's motivation in taking children under five year old to posyandu is variable education. From the result of this research, it's necessary to provide intensively about health promotion to motivate mothers to take children under five year old to posyandu.
\end{abstract}

Keyword : motivation, posyandu, knowledge, attitude,

\section{PENDAHULUAN}

Dalam rangka mewujudkan tujuan pembangunan kesehatan menuju Indonesia Sehat 2025, pemerintah dibawah Departemen Kesehatan mencanangkan berbagai program dibidang kesehatan. Program tersebut diharapkan mampu meningkatkan kesadaran, kemauan dan kemampuan hidup sehat bagi seluruh masyarakat diseluruh Indonesia.

Posyandu merupakan kegiatan nyata yang melibatkan orang tua, dan partisipasi masyarakat dalam pelayanan kesehatan dari masyarakat oleh masyarakat dan untuk masyarakat. Kegiatan posyandu dilaksanakan oleh kader-kader kesehatan yang telah mendapatkan pendidikan dan pelatihan dari puskesmas mengenai pelayanan kesehatan balita. Untuk suksesnya pelaksanaan dari kegiatan posyandu tergantung dari motivasi ibu dalam membawa balita ke posyandu tergantung dari motivasi ibu dalam membawa balita ke posyandu karena tanpa motivasi semua itu tidak akan terlaksana sesuai rencana dan tanpa motivasi orang tidak akan berbuat apa-apa dan tidak akan bergerak. Motivasi merupakan sesuatu yang menjadi pendorong tingkah laku yang menuntut atau mendorong seseorang untuk memenuhi kebutuhan. Faktor-faktor yang dapat berhubungan dengan motivasi ibu dalam membawa balita ke posyandu adalah unur balita, jumlah anak, 
tingkat pendidikan, pengetahuan ibu (Kemenkes RI,2013).

Sumatera Barat termasuk di Puskesmas Lubuk Basung program keterpaduan ini sudah berjalan sejak tahun 1984. Dari 7 kelurahan yang ada di wilayah kerja Puskesmas Lubuk Basung sudah berdiri 60 buah posyandu. Namun dalam perjalanannya selama ini sebagian dari posyandu ada yang kurang aktif.

Pertumbuhan pada balita dapat dipantau melalui penimbangan berat badan anak setiap bulan. Pemantauan pertumbuhan balita yang dilakukan setiap bulan menunjukkan bahwa presentase balita umur 6-59 bulan yang tidak pernah ditimbang dalam enam bulan terakhir cenderung meningkam enam bulan terakhir cenderung meningkat dari 25,5\% (2007),23,8\% (2010) menjadi 34,3\% (2013) (Kemenkes RI,2013).

Dari data yang ada di puskesmas Lubuk Basung menunjukan jumlah balita 2.900 jiwa yang rutin datang ke posyandu setiap bulannya hanya 1.306 jiwa atau 45\%. Pada kelurahan Balai Ahad jumlah balita 482 jiwa yang datang setiap bulannya 170 jiwa atau rata-rata $35 \%$, dan data yang diperoleh dari kader posyandu dengan jumlah balita 34 jiwa angka kunjungan hanya 11 jiwa atau kurang dari $37 \%$ disetiap bulannya. Data terakhir angka kunjungan balita ke posyandu hanya 12 jiwa atau $24 \%$ itu pun yang datang bayi yang berumur kurang dari satu tahun saja. Padahal posyandu bukan hanya untuk bayi yang berumur kurang dari satu tahun saja tetapi juga untuk balita usia satu sampai lima tahun.

Rendah kunjungan balita ke posyandu ini diduga karena rendahnya motivasi ibu membawa balitanya ke posyandu, sementara angka cakupan posyandu yang ditargetkan secara nasional adalah $80 \%$ (Notoatmodjo,2003). Pemerintah telah menetapkan rencana yang telah dibuat oleh kementrian kesehatan yaitu dengan menetapkan indikator: balita ditimbang berat badannyadan balita gizi buruk mendapatkan perawatan (Kemenkes RI, 2011).

Berdasarkan data yang diperoleh dari kader posyandu padahal pemerintah sudah berusaha memberikan pelayanan yang terbaik untuk kita bersama. Apabila dibiarkan situasi seperti ini terus berlanjut berkemungkinan 10 tahun yang akan datang tidak adanya masyarakat yang menggunakan posyandu sebagai pelayanan kesehatan balita.

\section{METODOLOGI PENELITIAN}

Penelitianinimerupakanpenelitiandeskriptif Desain yang digunakan adalah korelasional yang dikerjakan secara Cross Sectional. Populasi pada penelitian ini adalah ibu-ibu yang mempunyai bayi dan balita dengan jumlah populasi 30 orang.

\section{HASIL DAN PEMBAHASAN}

\section{Hasil}

\section{a. Analisa Univariat}

Dari hasil penelitian yang telah disebarkan melalui kuesioner dengan jumlah responden 30 orang.

\begin{tabular}{ccc}
$\begin{array}{c}\text { Tabel } 1 \text { Distribusi } \\
\text { Tingkat } \\
\begin{array}{l}\text { Dalam } \\
\text { Posyandu }\end{array}\end{array} \begin{array}{c}\text { Frekuensi } \\
\text { Pendidikan } \\
\text { Membawa }\end{array}$ & $\begin{array}{c}\text { Menurut } \\
\text { Responden } \\
\text { Balita ke }\end{array}$ \\
\hline Pendidikan & $\mathrm{f}$ & $\%$ \\
\hline Rendah & 9 & 30 \\
Tinggi & 21 & 70 \\
\hline Jumlah & 30 & 100 \\
\hline
\end{tabular}

Tabel 2 DistribusiFrekuensi Pengetahuan Responden Tentang Posyandu

\begin{tabular}{ccc}
\hline Pengetahuan & f & $\%$ \\
\hline Baik & 18 & 60 \\
Tidak baik & 12 & 40 \\
\hline Jumlah & 30 & 100
\end{tabular}


Tabel 3 DistribusiFrekuensi Sikap Responden Dalam Membawa Balita ke Posyandu Sayang Ibu

\begin{tabular}{ccc}
\hline Sikap & f & $\%$ \\
\hline Positif & 14 & 46,67 \\
Negatif & 16 & 53,33 \\
\hline & 30 & 100 \\
\hline
\end{tabular}

Tabel 4 DistribusiFrekuensi Dorongan Keluarga Dalam Membawa Balita ke Posyandu Sayang Ibu

\begin{tabular}{lcc}
\hline $\begin{array}{c}\text { Dorongan } \\
\text { Keluarga }\end{array}$ & $\mathbf{f}$ & \% \\
\hline $\begin{array}{l}\text { Baik } \\
\text { Tidak Baik }\end{array}$ & 18 & 60 \\
\hline Jumlah & 12 & 40 \\
\hline
\end{tabular}

Tabel 5 DistribusiFrekuensi Motivasi Responden Dalam Membawa Balita ke Posyandu Sayang Ibu

\begin{tabular}{lcc}
\hline \multicolumn{1}{c}{ Motivasi } & f & \% \\
\hline Baik & 6 & 20 \\
Tidak Baik & 24 & 80 \\
\hline Jumlah & 30 & 100 \\
\hline
\end{tabular}

\section{b. Analisa Bivariat}

Tabel 6 Hubungan Tingkat Pendidikan Dengan Motivasi Ibu Dalam Membawa Balita ke Posyandu

\begin{tabular}{ccccccc}
\hline Variabel & \multicolumn{4}{c}{ Motivasi } & \multicolumn{2}{c}{ Total } \\
\cline { 2 - 6 } $\begin{array}{c}\text { Tingkat } \\
\text { Pendidikan }\end{array}$ & \multicolumn{2}{c}{ Ada } & \multicolumn{2}{c}{ Tidak ada } & & \\
\cline { 2 - 7 } & f & $\mathbf{\%}$ & $\mathbf{f}$ & $\mathbf{\%}$ & f & \% \\
\hline Tinggi & 5 & 23,81 & 16 & 76,19 & 21 & 100 \\
\hline Rendah & 1 & 11,11 & 8 & 88,89 & 9 & 100 \\
\hline Total & 6 & & 24 & & 30 & \\
\hline
\end{tabular}

Hasil uji statistik penelitian didapatkan bahwa nilai chi-kuadrat hitung adalah 8,795 dan chi-kuadrat tabel adalah 7,81 yang mana chi-kuadrat hitung lebih besar dari chi-kuadrat posyandu.

tabel pada derajat kebebasan 3. Ini berarti ada hubungan yang bermakna antara pendidikan dengan motivasi ibu dalam membawa balita ke posyandu.
Tabel 7 Hubungan Tingkat Pengetahuan Dengan Motivasi Ibu Dalam Membawa Balita ke Posyandu

\begin{tabular}{ccccccc}
\hline Variabel & \multicolumn{4}{c}{ Motivasi } & \multicolumn{2}{c}{ Total } \\
\cline { 2 - 5 } Tingkat & \multicolumn{2}{c}{ Ada } & \multicolumn{2}{c}{ Tidak ada } & & \\
\cline { 2 - 7 } Pengetahuan & f & \% & f & \% & f & \% \\
\hline Baik & 6 & 33,33 & 12 & 66,67 & 18 & 100 \\
\hline Tidak baik & 0 & 0 & 12 & 100 & 12 & 100 \\
\hline Total & 6 & & 24 & & 30 & \\
\hline
\end{tabular}

Dari hasil uji statistik penelitian didapatkan bahwa nilai chi-kuadrat hitung adalah 8,125 dan chi-kuadrat tabel adalah 9,49 yang makna chi-kuadrat hitung lebih kecil dari chi-kuadrat tabel pada derajat kebebasan 4 . Ini berarti tidak ada hubungan yang bermakna antara pengetahuan dengan motivasi ibu dalam membawa balita ke posyandu.

Tabel 8 Hubungan Antara Sikap Dengan Motivasi Ibu Dalam Membawa Balita ke Posyandu

\begin{tabular}{ccccccc}
\hline $\begin{array}{c}\text { Variabel } \\
\text { Tingkat } \\
\text { Pengetahuan }\end{array}$ & \multicolumn{2}{c}{ Motivasi } & & \multicolumn{2}{|c}{ Total } & \\
\cline { 2 - 6 } & Ada & $\begin{array}{c}\text { Tidak } \\
\text { ada }\end{array}$ & & & & \\
\cline { 2 - 7 } & f & $\mathbf{\%}$ & f & \% & f & \% \\
\hline Baik & 4 & 28,57 & 10 & 71,43 & 14 & 100 \\
\hline Tidak baik & 2 & 12,5 & 14 & 87,5 & 16 & 100 \\
\hline Total & 6 & & 24 & & 30 & \\
\hline
\end{tabular}

Hasil uji statistik penelitian didapatkan bahwa nilai chi-kuadrat hitung adalah 11,250 dan chi-kuadrat tabel adalah 21 yang mana chikuadrat hitung lebih kecil dari chi-kuadrat tabel pada derajat kebebasan 12. Ini berarti tidak ada hubungan yang bermakna antara sikap dengan motivasi ibu dalam membawa balita ke

Tabel 9 Hubungan Tingkat Pengetahuan Dengan Motivasi Ibu Dalam Membawa Balita ke Posyandu

\begin{tabular}{ccccccc}
\hline Variabel & \multicolumn{4}{c}{ Motivasi } & \multicolumn{2}{c}{ Total } \\
\cline { 2 - 5 } Tingkat & \multicolumn{2}{c}{ Ada } & \multicolumn{2}{c}{ Tidak ada } & & \\
\cline { 2 - 6 } Pengetahuan & f & $\mathbf{\%}$ & f & \% & f & \% \\
\hline Baik & 5 & 27,78 & 13 & 72,22 & 18 & 100 \\
\hline Tidak baik & 1 & 8,33 & 11 & 91,67 & 12 & 100 \\
\hline Total & 6 & & 24 & & 30 & \\
\hline
\end{tabular}


Dari uji statistik penelitian didapatkan bahwa nilai chi-kuadrat hitung adalah 2,743 dan chi-kuadrat tabel adalah 7,81 yang mana chi-kuadrat tabel pada derajat kebebasan 3. Ini berarti tidak ada hubungan yang bermakna antara dorongan keluarga dengan motivasi ibu dalam membawa balita ke posyandu.

\section{Pembahasan}

\section{Analisa Univariat}

\section{Pendidikan}

Pendidikan merupakan proses pembelajaran formal yang dilalui oleh setiap responden yang diukur dengan ijazah terakhir. Pendidikan responden di lokasi posyandu Sayang Ibu pada umumnya sudah berpendidikan tinggi.

Sesuai dengan tabel distribusi frekuensi pada tabel 5.1.1 didapatkan responden berpendidikan tinggi adalah 21 responden atau $70 \%$ dan 9 responden atau 30\% responden yang berpendidikan rendah.

\section{Pengetahuan}

Pengetahuan merupakan hal-hal yang diketahui oleh responden tentang posyandu. Berdasarkan hasil kuesioner yang telah diberikan kepada responden pada umumnya tidak mengetahui tujuan dari posyandu ini disebabkan karena tidak adanya penyuluhan secara intensif oleh petugas kesehatan terhadap responden, seharunya responden telah mengetahui tujuan dari posyandu ini karena telah banyak promosi-promosi kesehatan yang telah dilakukan pemerintah untuk memberikan informasi tentang tujuan dari posyandu.

Dari hasil penelitian didapatkan $40 \%$ memiliki pengetahuan yang tidak baik terhadap posyandu karena tidak adanya penyuluhan secara intensif oleh petugas kesehatan yang berada dikawasan posyandu.

\section{Sikap}

Sikap merupakan pandangan atau keyakinan responden terhadap posyandu. Hasil penelitian didapatkan bahwa 46,67\% yang bersikap positif terhadap posyandu dan $53,33 \%$ yang bersikap negatif terhadap posyandu.

\section{Dorongan Keluarga}

Dorongan keluarga merupakan dukungan yang diberikan oleh keluarga pada responden untuk memotivasi responden untuk membawakeposyandu.

\section{Motivasi}

Motivasi merupakan keinginan responden untuk mengikuti kegiatan posyandu setiap bulannya. Hasil penelitian didapatkan 20\% ibu-ibu yang memiliki balita yang datang mengikuti kegiatan posyandu setiap bulannya.

Rendahnya motivasi responden dalam membawa balita ke posyandu disebabkan oleh latar belakang pendidikan yang berbeda-beda dan juga disebabkan kurangnya informasiinformasi atau penyuluhan yang diberikan oleh petugas kesehatan. Sehingga responden tidak mengetahui tujuan dan manfaat dari posyandu, responden tidak menyadari bahwa posyandu merupakan suatu kebutuhan. Kebutuhan akan muncul karena adanya sesuatu yang kurang dirasakan oleh seseorang. Dorongan merupakan arahan untuk memenuhi kebutuhan tersebut, sedangkan tujuan adalah akhir dari siklus motivasi (Nursalam, 2002).

\section{Analisa Bivariat}

Hubungan Pendidikan Dengan Motivasi Ibu Dalam Membawa Balita ke Posyandu

Dari uji statistik didapatkan bahwa ada hubungan yang bermakna antara pendidikan dengan motivasi ibu dalam membawa balita ke posyandu artinya semakin tinggi tingkat 
pendidikan seseorang maka tinggi pula motivasinya dalam membawabalita ke Posyandu. Menurut Notoatmodjo semakin tinggi tingkat pendidikan seseorang maka semakin tinggi pula keterampilan intelektual untuk melakukan sesuatu.

Penelitian ini didukung oleh penelitian sebelumnya yang diteliti oleh Afandi didapatkan hubungan yang bermakna pendidikan dengan motivasi ibu dalam membawa balita ke posyandu didapatkan 30 responden berpendidikan tinggi 14 responden (42\%) termotivasi dalam membawa balita ke posyandu dan 80 responden berpendidikan rendah 19 responden $(57,58 \%)$ termotivasi dalam membawa balita ke posyandu.

\section{Hubungan Tingkat Pengetahuan Tentang Posyandu Dengan Motivasi Ibu Dalam Membawa Balita ke Posyandu}

Hasil uji statistik didapatkan bahwa tidak ada hubungan yang bermakna antara pengetahuan antara pengetahuan dengan motivasi ibu dalam membawa balita ke posyandu artinya semakin tinggi tingkat pengetahuan ibu tetntang posyandu belum tentu bisa menjamin ibu untuk membawa balita ke posyandu dan semakin tidak baik tingkat pengetahuan ibu tentang posyandu maka semakin tidak akan termotivasi dalam membaw balita ke posyandu. Ini disebabkan karena responden tidak mengetahui sistem 5 meja yang ada di posyandu sehingga responden tidak mengetahui apa seharusnya yang bisa dapatkan di posyandu. Ini disebabkan karena tidak adanya penyuluhan secara intensif oleh petugas kesehatan tehadap responden yang memiliki balita, sehingga responden tersebut tidak mendapatkan informasi-informasi terbaru yang seharusnya didapatkan, akibatnya responden tersebut semakin tidak termotivasi dalam membawa balita ke posyandu.
Responden yang memiliki pengetahuan yang tinggi tentang posyandu tapi responden kurang termotivasi dalam membawa balita ke posyandu karena ditemukan bahwa ada $60 \%$ responden berpengetahuan baik terhadap posyandu karena menurut teori motivasi apabila seseorang mengetahui tentang keberadaan sesuatu maka ia akan menimbulkan kekuatan pada individu dan membawa seseorang untuk bertindak (Abdul Rahman, 2004).

Penelitian ini bertolak belakang dengan penelitian Suhasyril bahwa terdapat hubungan yang bermakna antara pengetahuan dengan motivasi ibu dalam membawa balita ke posyandu, didapatkan 63 responden berpengetahuan baik tentang posyandu 29 responden $(46,03 \%)$ termotivasi, 57 responden berpengetahuan cukup 11 responden $(19,29)$ termotivasi dalam membawa balita ke posyandu.

\section{Hubungan sikap dengan motivasi ibu dalam membawa balita ke posyandu}

Uji statistik didapatkan tidak ada hubungan yang bermakna antara sikap dengan motivasi ibu dalam membawa balita ke posyandu. Berdasarkan hasil wawancara terpimpin bahwa penyebab dari responden kurang termotivasi dalam membawa balita ke posyandu adalah sarana yang kurang memadai, ketidakpuasan responden ketika berkonsultasi dengan petugas disana sehingga responden bertambah tidak termotivasi dengan keadaan tersebut dan responden menganggap bahwa anak dibawa ke posyandu hanya sampai berumur 1 tahun.

Menurut teori motivasi bahwa motivasi tidak hanya datang dari individu tersebut tetapi juga datang dari luar individu(Widayatun,1999). Sikap mempunyai segi motivasi yang berarti dalam menuju suatu tujuan dan berusaha 
mencapai suatu tujuan tersebut (Purwanto,1999).

Penelitian ini bertolak belakang dengan penelitian Suhasyril bahwa terdapat hubungan yang bermakna antara sikap dengan motivasi ibu dalam membawa balita ke posyandu didapatkan 69 responden memiliki sikap yang baik 33 responden $(86,84 \%)$ termotivasi dalam membawa balita je posyandu dan 41 responden memiliki sikap kurang terhadap posyandu didapatkan 5 responden $(13,16 \%)$ termotivasi.

\section{Hubungan dorongan keluarga dengan motivasi ibu dalam membawa balita ke posyandu}

Dari uji statistik didapatkan bahwa tidak ada hubungan yang bermakna antara dorongan keluarga dengan motivasi ibu dalam membawa balita ke posyandu artinya walaupun dorongan dari keluarga tinggi untuk memotivasi menjamin seseorang untuk termotivasi, padahal menurut teori motivasi merupakan suatu tenaga dinamis manusia dan munculnya memerlukan rangsangan baik dari dalam maupun dari luar (Purwanto, 1999).

Penelitian ini bertolak belakang dengan penelitian sebelumnya diteliti Afandi didapatkan bahwa terdapat hubungan yang bermakna antara dorongan keluarga dengan motivasi dalam membawa balita ke posyandu.

\section{KESIMPULAN DAN SARAN}

Berdasarkan hasil penelitian ini, maka kesimpulan yang didapatkan adalah sebagai berikut :

a. Sebagian besar responden berpendidikan tinggi. b. Sebagian responden berpengetahuan baik tentang posyandu.

c. Kurang dari separoh responden yang bersikap positif terhadap posyandu.

d. Sebagian besar responden mendapatkan dukungan keluarga

e. Lebih dari separoh responden kurang termotivasi membawa balita ke posyandu.

f. Terdapat hubungan yang bermakna antara tingkat pendidikan dengan motivasi ibu dalam membawa balita ke posyandu.

g. Tidak terdapat hubungan yang bermakna antara pengetahuan tentang posyandu dengan motivasi ibu dalam membawa balita ke posyandu.

h. Tidak terdapat hubungan yang bermakna antara sikap dengan motivasi ibu dalam membawa balita ke posyandu.

i. Tidak terdapat hubungan yang bermakna antara dorongan keluarga dengan motivasi ibu dalam membawa balita ke posyandu.

\section{DAFTAR PUSTAKA}

Afandi Dedi .(1999). Prilaku ibu-ibu Anak Balita Terhadap Kunjung ke Posyandu di Kelurahan Jati Rawang Kecamatan Padang Timur Kodya Padang.

Budiarto Eko. (2016). Metodologi Penelitian Kedokteran. Jakarta.EGC

Effendy Nasrul. (1998). Dasar-dasar Keperawatan Kesehatan Masyarakat. Jakarta.EGC.

Kemenkes RI.2011. Panduan Penyelenggaraan Pemberian Makanan Tambahan Pemulihan Bagi Balita Gizi Kurang, Bantuan Operasional Kesehatan. Jakarta. Ditjend Bina Gizi dan KIA.

Kemenkes RI.2012. Ayo ke Posyandu Setiap Bulan. Jakarta.Pusat Promosi Kesehatan Kementrian Kesehatan RI. 
Matondang Corrys, dkk. (2003). Diagnosa Fisik Pada Anak. Jakarta. CV.Sagung Seto.

Nursalam. (2002). Manajemen Keperawatan Aplikasi Dalam Praktek Keperawatan Profesional. Jakarta. Salemba Medika.

Nursalam.(2003). Konsep dan Penerapan Metodologi Penelitian Ilmu Keperawatan. Salemba Medika.

Notoatmodjo Soekidjo.(2003). Ilmu Kesehatan Masyarakat Prinsip-prinsip Dasar. Jakarta.Rineka Cipta.

Notoatmodjo Soekidjo.(2003). Pendidikan dan perilaku Kesehatan. Jakarta. Rineka Cipta.

PurwantoHeri.(1999). Pengantar Perilaku Manusia untuk keperawatan. Jakarta.EGC.

Shaleh Rahman Abdul dan Wahab Abdul Muhhib.(2004). Psikologi Pengantar Dalam Perspektif Islam. Jakarta.Prenada Media.
Siagian P Sondang.(2004). Teori Motivasi dan Aplikasinya. Jakarta. Rineka Cipta.

Sulaiman Wahid.(2002). Jalan Pintas Menguasai SPSS10. Yogyakarta. Andi.

Suryanah.(1996). Keperawatan Anak Untuk Siswa SPK. Jakarta.EGC.

Widayatun Rusmi Tri.(1999). Ilmu Prilaku.Jakarta.CV.Sagung Seto.

Z.A. Suhasyril.(1995). Gambaran Kunjungan Ke Posyandu di Berapa Kelurahan Pada Kecematan Padang Barat Tahun 1992/1993 serta faktor-faktor yang mempengaruhinya. Departemen pendidikan dan kebudayaan. Padang. (2002). Buku Kesehatan Ibu dan Anak. Departemen Kesehatan RI. Indonesia. 